\title{
The Role of CD 34 Hematopoietic Progenitor Cells, Macrophages, and Smooth Muscle Cells in Human Coronary Artery Atherogenesis
}

\author{
Sally Said Kamel ${ }^{1}$, Ahmed Mahmoud Abdel-Aziz ${ }^{2}$, Mostafa Mohamed Salem², Hebat Allah A. Amin ${ }^{1,3 *}$ \\ ${ }^{1}$ Department of Pathology, Egyptian Forensic Medicine Authority, Cairo, Egypt; ${ }^{2}$ Department of Pathology, Faculty of Medicine, \\ Kasr AlAiny, Cairo, Egypt; ${ }^{3}$ Department of Pathology, Faculty of Medicine, Helwan University, Cairo, Egypt
}

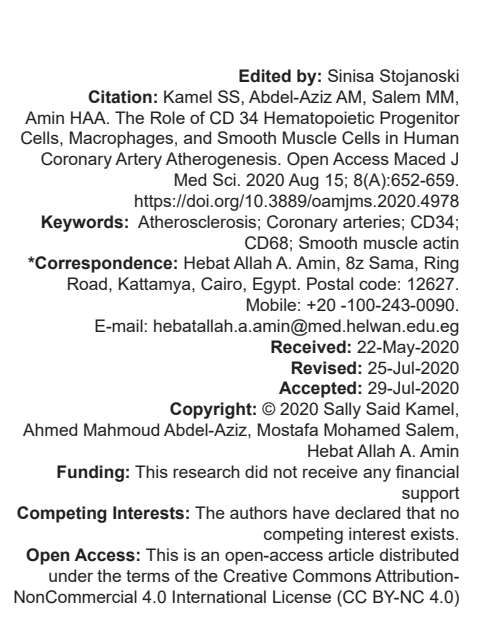

\begin{abstract}
BACKGROUND: Atherosclerosis is a widespread and devastating disease and one of the leading causes of death worldwide. So much is there to understand about atherosclerosis. And although a lot is already discovered, yet most of the studies are performed in cell cultures and animal models. Recent technologies for genetic engineering and imaging are mainly performed on animal models, with few studies in human tissues. A better understanding of their role is required.

AIM: We aim to study the expression of CD 34 hematopoietic progenitor stem cell, CD 68 macrophages, and smooth muscle actin (SMA)-positive smooth muscle cells (SMCs) in the human coronary arteries and correlate their differential expression with the atherosclerosis progression.

RESULTS: CD 68 and CD 34 expression increase as the atherosclerotic process proceeds from early atheroma to advanced atheroma and start to decrease as the process proceeds to fibroatheroma with a significant $p<0.001$. Conversely, SMA expression decreases as the atherosclerotic process progresses with a significant $p<0.001$.

CONCLUSION: CD34 progenitor cells in conjunction with CD 68 macrophages have a major role in the development of atherosclerosis, whereas the SMCs are minimal in the early stages and reach their maximal levels during the stage of fibroatheroma.
\end{abstract}

\section{Introduction}

Atherosclerosis remains an increasingly important disease worldwide. It accounts for nearly one-third of deaths in ages over 35 years [1]. Despite the tremendous progress in biomedical sciences, it is still considered one of the great challenges in medicine due to its complex pathogenesis [2].

Atherosclerosis produces slow coronary narrowing resulting in stable angina and pain on exertion. Furthermore, the plaque rupture produces acute coronary syndromes presenting as unstable angina, myocardial infarction, or even sudden death [3].

Various risk factors, such as obesity, diabetes mellitus, hypertension, stress, cigarette smoking, hypercholesterolemia, gout, and familial predisposition can affect the progression of atherosclerosis [4], [5].

It is agreed on that atherosclerosis starts with endothelial dysfunction then increased adherence of monocytes/macrophages and T-lymphocytes. Monocyte/macrophage infiltrate in the sub-endothelial space accompanied by serum lipid permeation, then the migration of medial smooth muscle cells (SMC) into the intima [6].

In addition to their role in lipid uptake, macrophages have a central role in the inflammatory response involved in plaque progression [7].

Accumulating evidence suggests that subset of hematopoietic stem cells circulating in the blood is involved in atherogenesis. Zulli et al. (2005) on their experimental study on rabbits reported that CD34positive cells are present within the atherosclerotic plaques of rabbits fed high dietary cholesterol [8]. Recently, a role of CD 34 was detected in inflammatoryerosive plaques [9].

The vascular SMCs (VSMCs) comprise a major contributor to atherosclerotic plaque development and progression. They have been detected at all stages of atherosclerosis [10]. It has been noticed that there is an interplay between CD34-positive hematopoietic cells with SMCs and macrophage in a rabbit atherosclerotic model [8].

Furthermore, a more recent study by Kruzliak et al. (2016) has reported that the predominant cell population in a fibrous cap was the VSMCs CD34 
$(-v e) /$ smooth muscle actin (SMA) (+ve). Few CD34 $(+\mathrm{ve}) / \mathrm{SMC}(+\mathrm{ve})$ cells were also present in a similar animal model [11].

Relatively recent studies suggest that small, non-stenotic atherosclerotic lesions account for the majority of ruptured plaques [12]. This worrisome postulation needs to be investigated. However, it seems that the experimental animal models have not provided a full explanation of the atherosclerosis progression. In humans, we mainly rely on epidemiological studies [13].

Herein, we decided to perform a postmortem study on human coronaries. We aim to examine the role of CD34 hematopoietic stem cells in human atherosclerotic tissues and to compare their role with that of macrophages and SMCs in various stages of atherosclerosis. This may shed some light on the role of these three main contributors of atherosclerosis on atherogenesis and plaque progression.

\section{Materials and Methods}

\section{Study design}

A cross-sectional observational study was conducted in the pathology department of the Egyptian Forensic Medicine Authority (EFMA). It included coronary artery segments obtained from 61 autopsy cases admitted to the Pathology Department in the period between 2014 and 2015.

Anonymous data are collected including the age, gender, and residence of the deceased. The gross and microscopic findings of the examined hearts were recorded, together with the reported causes of deaths. The study and all the procedures were approved by the EFMA.

\section{Heart and coronary dissection}

The hearts were weighed, measured, and externally examined to assess the cardiac and pericardial external gross appearance [Figure (A-1)]

The course and pattern of the coronary arteries were assessed [14]

The coronary arteries were serially cut by transverse incisions, 3-5 $\mathrm{mm}$ interval [15]

We started with the common left coronary (LCA), then the anterior descending branch - the continuity of the LCA. Then, circumflex and the right coronary artery were followed

If a gross pathology was noticed, sections taken may reach 10-15 from one coronary.

\section{Tissues}

After samples were excised, they were fixed in $10 \%$ neutral-buffered formalin

Tissue sections, from coronaries, were routinely processed and embedded in paraffin

Paraffin blocks are made and serial sections of 4 micron thickness are prepared. Sections are stained with H\&E for routine microscopic examination.

\section{Histopathological evaluation}

The degree of stenosis of the coronary was reported and the grade of the atheroma was evaluated

Histological typing of atherosclerotic lesions followed the American Heart Association classification [16] coronaries)

Early lesions are types I, II, and III (25 coronaries)

Advanced lesions are types IV, V, and VI (36

\section{Selection of sections for} immunohistochemistry

Finally, sections of the coronary arteries were submitted for immunohistochemical staining by CD 34 , CD 68, and SMA.

\section{Immunohistochemistry}

Histological sections approximately $4 \mu \mathrm{m}$ thick were deparaffinated in xylene and alcohol and then rehydrated in distilled water for $5 \mathrm{~min}$. Then, they were washed in PBS for 5 min

Sections were pretreated with the proteolytic enzyme proteinase K (Dako, Copenhagen, Denmark), for antigen retrieval. This was followed by a wash in PBS for 5 min

Non-immune protein blocking serum was added and incubated in a humid chamber

Primary antibodies for CD34, CD68, and SMA (Dako, Copenhagen, Denmark) were used

The primary monoclonal antibodies CD34, $\mathrm{CD68}$, and SMA were incubated for 60 minutes at $37^{\circ} \mathrm{C}$, followed by PBS wash for $5 \mathrm{~min}$

The secondary antibody was applied for 60 min (Dako, Copenhagen, Denmark)

Two drops of the horseradish peroxidaseconjugated streptavidin were added followed by incubation for $60 \mathrm{~min}$. Then, rinsing with PBS was done

Finally, the reaction was visualized with $D A B$ chromogen (Dako, Copenhagen, Denmark) 
Slides were counterstained with dilute hematoxylin, rinsed with ammonia, and then with tap water. Sections were dehydrated with graded ethanol, cleared in xylene, and then coverslipped.

\section{Immunohistochemical Evaluation}

The distribution of staining for CD34, CD68, and SMA is assessed in every section

Manual counting of positively stained cells in the most advanced lesion in the atheromatous plaque is performed using fields at $\times 400$. As regard the SMCs, the counted cells are those proliferating cells within the atheromatous plaque. The stained regular mature SMCs of the media are omitted.

\section{Statistical Analysis}

All results are expressed as the mean standard errors of the mean. Statistical analysis is conducted using an analysis of variance using SPSS v 16. Results are considered to be statistically significant at $p<0.05$.

\section{Results}

The results are summarized in Tables 1-3.

The age ranged from $4^{\text {th }}$ to $8^{\text {th }}$ decade, nine cases are in the $4^{\text {th }}$ decade $(14.8 \%), 25$ are in the $5^{\text {th }}$ decade $(41 \%), 12$ are in the $6^{\text {th }}$ decade $(19.7 \%), 10$ are in the $7^{\text {th }}$ decade $(16.4 \%)$, two are in the $8^{\text {th }}$ decade $(3.3 \%)$, and three cases are unknown (4.9\%).

Advanced atheroma is more prevalent in the $4^{\text {th }}$ decade; while fibroatheroma is more detected in the $6^{\text {th }}$ decade. Calcified atheromatous plaques are more encountered in the $7^{\text {th }}$ decade.

This study included 61 cases, $91.8 \%$ are male, $3.3 \%$ are female, and $4.9 \%$ had no available data (referred anonymously to the laboratory).

Regarding the grade of atherosclerosis in a given coronary artery, $12(19.7 \%)$ arteries show early atherosclerotic changes, 13 (21.3\%) arteries show atheroma type III, and two cases (3.3\%) have advanced atheromas, and type IV, one of which showed obstructed lumen by a recent thrombus. Thirty-four $(55.7 \%)$ arteries have fibroatheromas and complicated fibroatheromas, types $\mathrm{V}$ and VI.

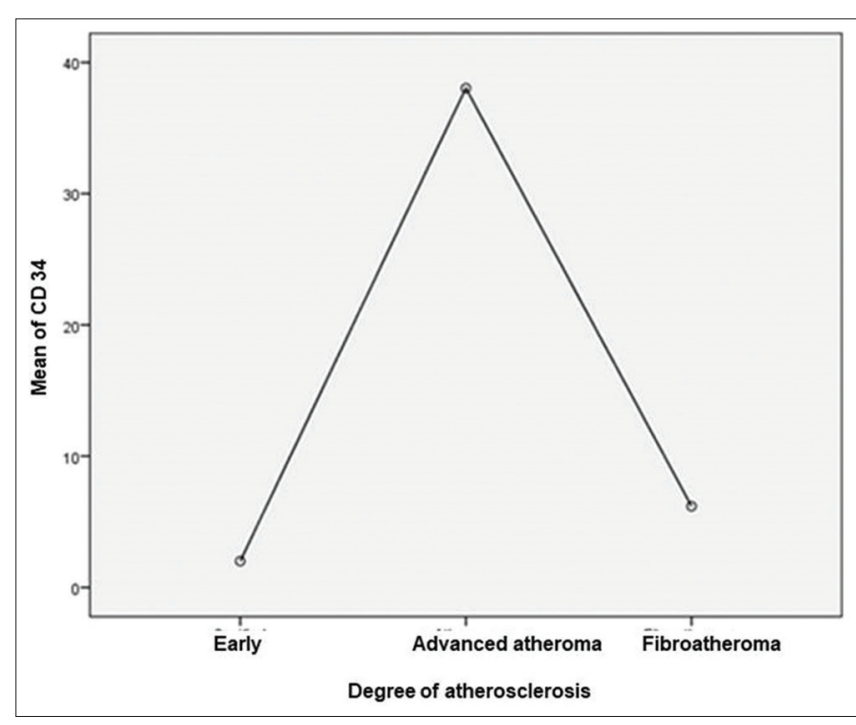

Figure 1: $C D 34$ expression in the atherosclerotic plaque with relation to the grade of atherosclerosis

Regarding the degree of stenosis, 15 (24.6\%) cases are not associated with stenosis, 23 (37.7\%) cases showed mild stenosis, $12(19.7 \%)$ cases showed moderate stenosis, nine $(14.8 \%)$ cases showed severe stenosis, and $2(3.3 \%)$ cases showed complete occlusion of the coronary lumen.

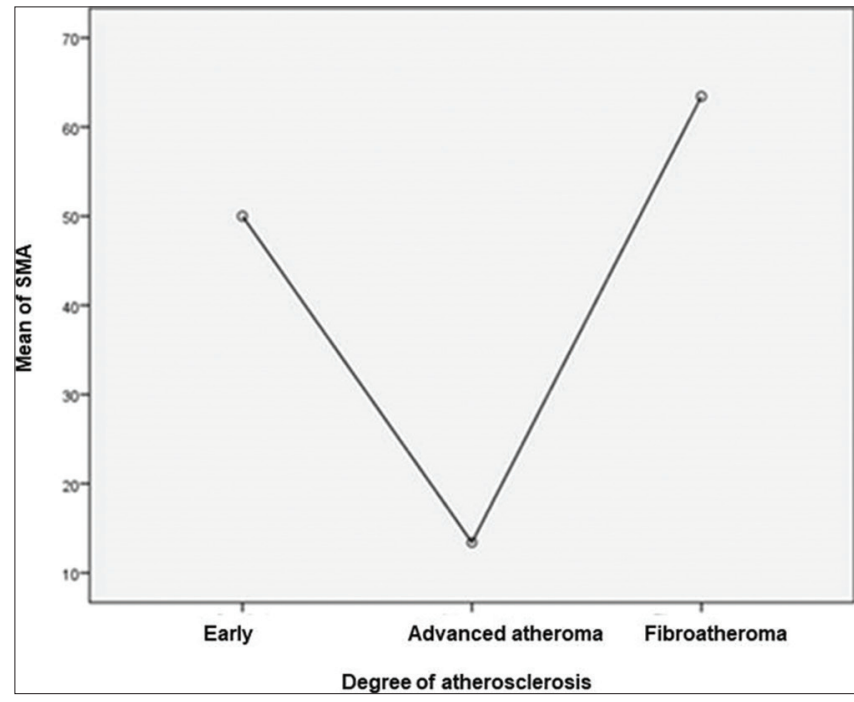

Figure 2: SMA expression in the atherosclerotic plaque with relation to the grade of atherosclerosis

Eight $(13.2 \%)$ cases were associated with calcification, one of which was associated with hemorrhage and rupture.

Table 1: CD68 expression in the atherosclerotic plaque with relation to the grade of atherosclerosis

\begin{tabular}{|c|c|c|c|c|c|c|c|c|}
\hline \multirow[t]{2}{*}{ Variables } & \multirow[t]{2}{*}{$\mathrm{N}$} & \multirow[t]{2}{*}{ Mean } & \multirow[t]{2}{*}{ SD. } & \multicolumn{2}{|c|}{ 95\% confidence interval for mean } & \multirow[t]{2}{*}{ Minimum } & \multirow[t]{2}{*}{ Maximum } & \multirow[t]{2}{*}{$p$-value } \\
\hline & & & & Lower bound & Upper bound & & & \\
\hline Ruptured plaque (VI) & 1 & 1.00 & & & & 1 & 1 & $<0.001$ \\
\hline Atheroma (I-CD68 IV) & 27 & 49.56 & 17.603 & 42.59 & 56.52 & 15 & 77 & \\
\hline Fibroatheroma (V) & 33 & 7.58 & 9.549 & 4.19 & 10.96 & 1 & 40 & \\
\hline Total & 61 & 26.05 & 25.094 & 19.62 & 32.48 & 1 & 77 & \\
\hline
\end{tabular}




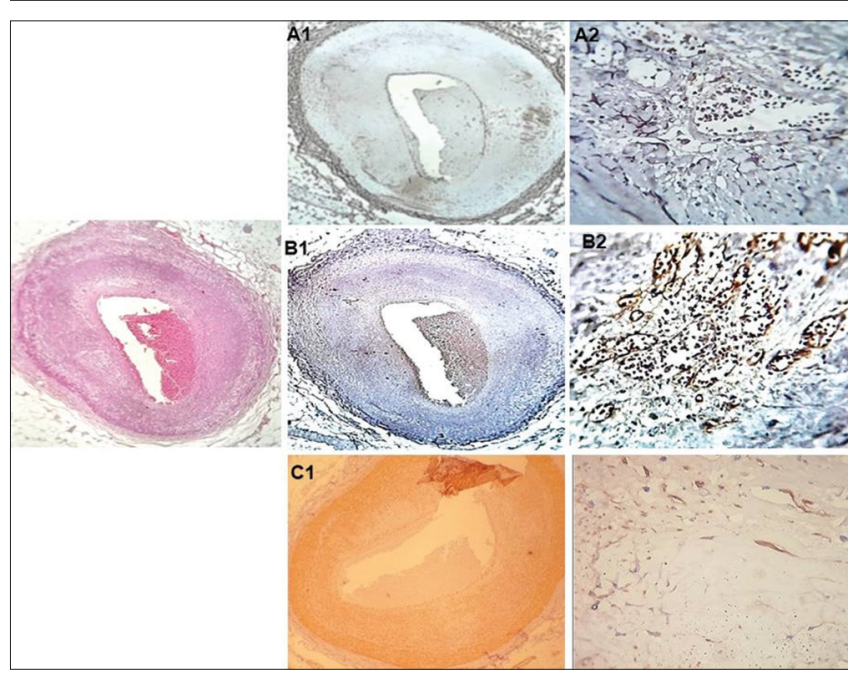

Figure 3: A) $C D 68$ strong expression in early atherogenesis; $B$ ) $C D 34$ strong expression in early atherogenesis; C) Actin weak expression in atheroma (only the small proliferating small cells are counted

It was found that CD 68 expression increases as the atherosclerotic process proceeds from early atheroma to advanced atheroma and starts to decrease as the process proceeds to fibroatheroma with significant $p<0.001$ (Table 1 and Figures 1 and 4).

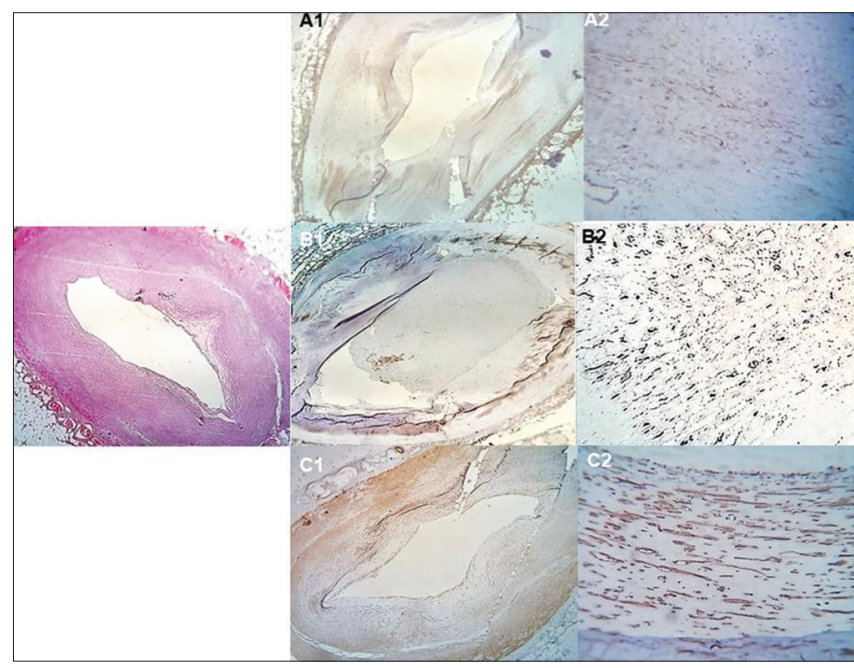

Figure 4: A) $C D 68$ weak expression in fibroatheroma; B) $C D 34$ Weak expression in fibroatheroma; C) Actin strong expression in fibroatheroma

CD 34 expression also increases as the atherosclerotic process proceeds from early atheroma to advanced atheroma, then starts to decrease as the process proceeds to fibroatheroma with significant $p<$ 0.001 (Table 2 and Figures 2 and 5).

It is noticed that SMA expression is minimal as the atherosclerotic process proceeds from early atheroma to advanced atheroma and starts to increase as the process proceeds to fibroatheroma with significant $p<0.001$ (Table 3 and Figure 3).

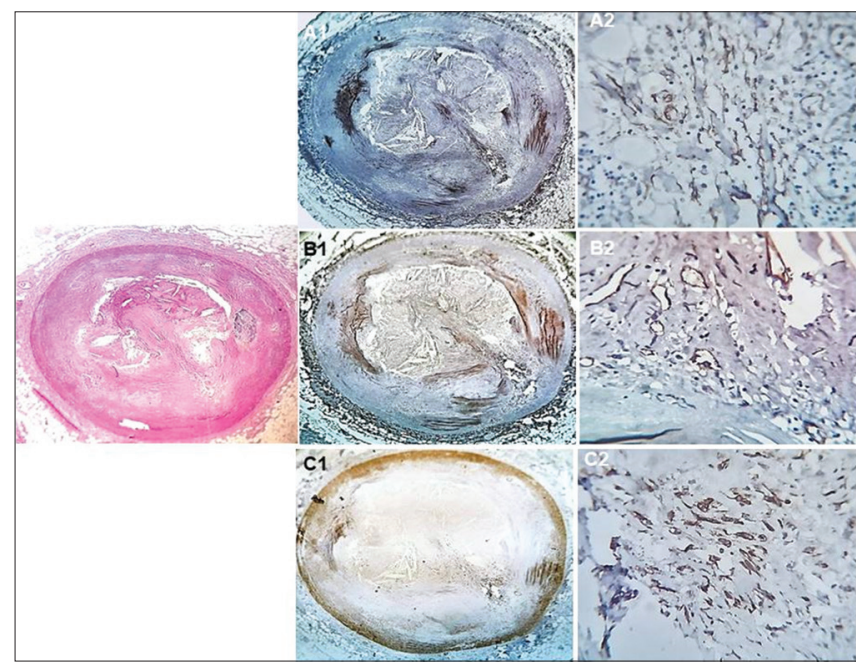

Figure 5: A) CD 68 strong expression in thrombosed vessel; B) $C D 34$ strong expression in thrombosed vessel; C) Actin strong expression in thrombosed vessel

\section{Discussion}

Atherosclerosis is a slow progressive disease process that starts in childhood. It may progress rapidly in some individuals by their 30s. However, in others, it may only progress after the $5^{\text {th }}$ decade. The exact pathogenesis of atherosclerosis and its progression are not well recognized.

Table 2: CD34 expression in the atherosclerotic plaque with relation to the grade of atherosclerosis

\begin{tabular}{|c|c|c|c|c|c|c|c|c|}
\hline \multirow[t]{2}{*}{ Variables } & \multirow[t]{2}{*}{$\mathrm{N}$} & \multirow[t]{2}{*}{ Mean } & \multirow[t]{2}{*}{ SD } & \multicolumn{2}{|c|}{$\begin{array}{l}95 \% \text { confidence } \\
\text { interval for mean }\end{array}$} & \multirow[t]{2}{*}{ Minimum } & \multirow[t]{2}{*}{ Maximum } & \multirow[t]{2}{*}{$\mathrm{p}$-value } \\
\hline & & & & $\begin{array}{l}\text { Lower } \\
\text { bound }\end{array}$ & $\begin{array}{l}\text { Upper } \\
\text { bound }\end{array}$ & & & \\
\hline $\begin{array}{l}\text { Ruptured } \\
\text { plaque (VI) }\end{array}$ & 1 & 2.00 & & . & . & 2 & 2 & $<0.001$ \\
\hline $\begin{array}{l}\text { Atheroma } \\
\text { (I-IV) CD34 }\end{array}$ & 27 & 38.04 & 11.663 & 33.42 & 42.65 & 13 & 65 & \\
\hline $\begin{array}{l}\text { Fibroatheroma } \\
\text { (V) }\end{array}$ & 33 & 6.18 & 11.148 & 2.23 & 10.13 & 1 & 65 & \\
\hline Total & 61 & 20.21 & 19.545 & 15.21 & 25.22 & 1 & 65 & \\
\hline
\end{tabular}

According to our study, $91.8 \%$ of the cases were male. These results are biased by the fact that the number of susceptible females subjected to forensic autopsy in Egypt is much lesser than males. Thus, this figure does not reflect the actual epidemiological prevalence of the disease. 
Table 3: SMA expression in the atherosclerotic plaque with relation to the grade of atherosclerosis

\begin{tabular}{|c|c|c|c|c|c|c|c|}
\hline \multirow[t]{2}{*}{ Variables } & \multirow[t]{2}{*}{$n$} & \multirow[t]{2}{*}{ Mean } & \multirow[t]{2}{*}{ SD } & \multicolumn{2}{|c|}{$\begin{array}{l}95 \% \text { confidence } \\
\text { interval for mean }\end{array}$} & \multirow[t]{2}{*}{ Minimum } & \multirow[t]{2}{*}{$\begin{array}{l}\text { Maximum } \\
\text { p-value }\end{array}$} \\
\hline & & & & $\begin{array}{l}\text { Lower } \\
\text { bound }\end{array}$ & $\begin{array}{l}\text { Upper } \\
\text { bound }\end{array}$ & & \\
\hline Ruptured plaque (VI) & 1 & 50.00 & & & & 50 & $50<0.001$ \\
\hline Atheroma (I-Actin IV) & 27 & 13.41 & 15.564 & 7.25 & 19.56 & 1 & 55 \\
\hline Fibroatheroma (V) & 33 & 63.42 & 22.751 & 55.36 & 71.49 & 15 & 100 \\
\hline Total & 61 & 41.07 & 31.647 & 32.96 & 49.17 & 1 & 100 \\
\hline
\end{tabular}

In the present study, the most prevalent age for advanced atheroma is the $4^{\text {th }}$ decade; the most prevalent age for fibroatheroma is the $6^{\text {th }}$ decade while the most prevalent age for calcifications in the atheromatous plaque is the $7^{\text {th }}$ decade. Thus, we have noticed lesional progression with age. Over $55 \%$ of the studied cases are under the age of 50 .

Some studies claim that the plaques responsible for myocardial infarctions and other acute coronary syndromes often are asymptomatic before the acute event. The worrisome conclusion is that large numbers of asymptomatic individuals are at risk for a catastrophic coronary event [17]. One of the two reported cases of acute coronary syndrome showed only $60 \%$ stenosis (i.e., asymptomatic).

CD 68 is used as a marker for macrophages, CD 34 as a marker for the hematopoietic stem cells, and SMA as a marker for the SMCs.

Macrophages are considered the key promoters of the atherogenic process. A significant and independent correlation between blood monocyte-macrophage count and the atherosclerotic vascular disease in humans have been previously documented [18].

CD68 expression also increases in conjunction with the CD 34 expression as the atherosclerotic process proceeds from early atheroma to advanced atheroma and then the expression of both starts to decrease as the process proceeds to fibroatheroma (Figure 1).

The different cell types in the atherosclerotic plaque have always been a subject of debate amongst researchers in the field of medical research. Accumulating evidence indicates that bone marrowderived progenitor cells, including endothelial progenitor cells and smooth muscle progenitor cells, are involved in atherogenesis, and that these progenitors differentiate into mature and functional SMCs [19], [20].

Qingbo (2006) suggests that progenitor cells recruited from the blood and the vessel adventitia migrate into the intima, where they proliferate. This is enhanced by increased endothelial turnover, as well as the promotion of smooth muscle and macrophage accumulation in the plaques. Hence, the progenitor cells are thought to provide the main cell source responsible for the formation of atherosclerotic lesions [21].

This is strongly evident in our study as we have noticed an increased number of CD 34 in the intima and adventitia, of the atherosclerotic vessels, especially in the early atherogenesis (Figures $4 \mathrm{~A} 1$ and B1).
We have found that CD 34 expression increases as the atherosclerotic process proceeds from early atheroma to advanced atheroma and starts to decrease as the process proceeds to fibroatheroma (Figure 2).

Conversely, SMA expression is minimal as the atherosclerotic process proceeds from early atheroma to advanced atheroma and starts to increase as the process proceeds to fibroatheroma (Figure 3 ).

Feil et al., 2014, and Chappell et al., 2016, proposed that the SMC population of the intima is derived from a subset of medial SMC after vascular injury in experimental models of atherosclerosis [22], [23]

Grebe and Latz (2013) proposed that plaques with large numbers of foam cells and abundant extracellular lipid, as well as plaques that have thin fibrous caps containing few SMCs, and those that contain clusters of inflammatory cells are particularly high risk. Herein, increased expression of the three types of cells is noticed in these complicated lesions. This is in contrast to our findings in other stable plaque lesions, where the levels of CD 34 and CD 68 decline with plaque progression. Thus, a suggested role of these cells in plaque instability needs to be investigated [24].

Some experimental studies described these vulnerable plaques. As fibrous cap undergoes continuous remodeling; its stability is directly proportional to the collagen deposition. It is proposed that the balance of collagen synthesis and degradation affects cap integrity. Collagen in atherosclerotic plaques is synthesized primarily by SMCs, and loss of SMCs understandably results in cap weakening [25]. Again this is contradictory to our findings in these two cases of acute coronary syndrome where increased SMCs were detected in the complicated lesions. A previous study suggests that activated macrophages can accelerate the proatherogenic functions of SMCs in plaques [26]. It was also suggested that dynamic interactions between SMCs and macrophages could affect the pathogenesis of plaques and the development of new classes of medical solutions [27]. Other studies attributed variable behaviors and roles of SMCs attributed to the variation in their embryological origins as well as their phenotypic switch [28].

In general, it is accepted that the inflammation promotes collagen degradation, thus destabilizing the plaque integrity. Stable plaques usually show a dense fibrous cap, with less inflammation, whereas unstable plaques have relatively thin caps and increased inflammatory infiltrates [17].

We recorded increased numbers of CD 34 and CD 68-positive cells in complicated lesions. Furthermore, the degraded smooth muscles were increased in these complicated lesions (Figures 6). 


\section{Conclusion}

In conclusion, human progenitor stem cells and macrophages are increased with almost the same proportion during the progression of atherosclerosis till the stage of advanced atheroma where they both reach their maximum and then start to decrease till they both reach their minimal expression in the stage of fibroatheroma.

Meanwhile, the SMCs are minimal in the early stages and reach the lowest value during advanced atheroma stage and start to increase to reach their maximal levels during the stage of fibroatheroma.

The role of inflammatory cytokines is well noted as they activate the metalloproteinases leading to smooth muscle degradation resulting in plaque instability. $\quad$ Further immunopathologic studies on the types of inflammatory cytokines expressed in early atheromas can provide new therapeutic opportunities that can be used as prophylaxis from the acute coronary syndrome.

\section{References}

1. World Health Organization. The Top 10 Causes of Death. Geneva: World Health Organization; 2018. Available from: https://www.who.int/news-room/fact-sheets/detail/the-top-10causes-of-death. [Last accessed on 2020 Jan 10].

2. Sanchis-Gomar F, Perez-Quilis C, Leischik R, Lucia A Epidemiology of coronary heart disease and acute coronary syndrome. Ann Transl Med. 2014;4(13):256. https://doi. org/10.21037/atm.2016.06.33

PMid:27500157

3. BoyleJJ.Macrophageactivation in atherosclerosis:Pathogenesis and pharmacology of plaque rupture. Curr Vasc Pharmacol. 2005;3(1):63-8. https://doi.org/10.2174/1570161052773861 PMid:15638783

4. Rodríguez-Flores $M$, Rodríguez-Saldaña J, Cantú-Brito C, Aguirre-García J, Alejandro GG. Prevalence and severity of atherosclerosis in different arterial territories and its relation with obesity. Cardiovasc Pathol. 2013;22(5):332-8. https://doi. org/10.1016/j.carpath.2013.01.008

PMid:23465353

5. Hegyi L, Hardwick SJ, Siow RC. Macrophage death and the role of apoptosis in human atherosclerosis. J Hematother Stem Cell Res. 2001;10(1):27-42.

PMid: 11276357

6. Akishima $Y$, Akasaka $Y$, Ishikawa $Y$, Lijun Z, Kiguchi H, Ito K, et al. Role of macrophage and smooth muscle cell apoptosis in association with oxidized low-density lipoprotein in the atherosclerotic development. Mod Pathol. 2005;18(3):365-73. https://doi.org/10.1038/modpathol.3800249

PMid:15319783

7. Bobryshev YV, Nikiforov NG, Elizova NV, Orekhov AN. macrophages and their contribution to the development of atherosclerosis. Results Probl Cell Differ. 2017;62:273-98. https://doi.org/10.1007/978-3-319-54090-0_11

\section{PMid:28455713}

8. Zulli A, Buxton BF, Black MJ, Hare DL. CD34 class III positive cells are present in atherosclerotic plaques of the rabbit model of atherosclerosis. Histochem Cell Biol. 2005;124(6):517-22. https://doi.org/10.1007/s00418-005-0072-2

PMid: 16177890

9. Murashov IS, Volkov AM, Kazanskaya GM, Kliver EE, Chernyavsky AM, Nikityuk DB, et al. Immunohistochemical features of different types of unstable atherosclerotic plaques of coronary arteries. Bull Exp Biol Med. 2018;166(1):102-6. https:// doi.org/10.1007/s10517-018-4297-1 PMid:30417299

10. Allahverdian S, Chehroudi AC, McManus BM, Abraham T, Francis GA. Contribution of intimal smooth muscle cells to cholesterol accumulation and macrophage-like cells in human atherosclerosis. Circulation. 2014;129(15):1551-9. https://doi. org/10.1161/circulationaha.113.005015 PMid:24481950

11. Kruzliak P, Hare DL, Sabaka P, Delev D, Gaspar L, Rodrigo L, et al. Evidence for CD34/SMA positive cells in the left main coronary artery in atherogenesis. Acta Histochem. 2016;118(4):413-7. https://doi.org/10.1016/j.acthis.2016.04.005 PMid:27087050

12. Fearon WF. Is a myocardial infarction more likely to result from a mild coronary lesion or an Ischemia-producing one? Circ Cardiovasc Interv. 2011;4(6):539-41. https://doi.org/10.1161/ circinterventions.111.966416 PMid:22186104

13. Fishbein MC, Fishbein GA. Arteriosclerosis: Facts and fancy. Cardiovasc Pathol. 2015;24(6):335-42. https://doi.org/10.1016/j. carpath.2015.07.007।

PMid:26365806

14. Sheaff MT, Hopster DJ. The Cardiovascular system. In: Post Mortem Technique Handbook. $2^{\text {nd }}$ ed. Berlin, Germany: Springer; 2005. p. 141-79.

15. Schoen FJ. Blood vessels. In: Pathologic Basis of Disease. $7^{\text {th }}$ ed. Philadelphia, PA: Elsevier Saunders; 2005. p. 511-54.

16. Stary HC, Chandler AB, Dinsmore RE, Fuster V, Glagov $\mathrm{S}$, Insull W Jr., et al. A definition of advanced types of atherosclerotic lesions and a histological classification of atherosclerosis. A report from the committee on vascular lesions of the council on arteriosclerosis, American heart association. Circulation. 1995;92(5):1355-74. https://doi. org/10.1161/01.cir.92.5.1355

\section{PMid:7648691}

17. Hansson GK, Libby P, Tabas I. Inflammation and plaque vulnerability. J Intern Med. 2015;278(5):483. https://doi. org/10.1111/joim.12406

PMid:26260307

18. Murphy AJ, Tall AR. Proliferating macrophages populate established atherosclerotic lesions. Circ Res. 2014;114(2):2368. https://doi.org/10.1161/circresaha.113.302813

19. Du F, Zhou J, Gong R, Huang X, Pansuria M, Virtue A, et al Endothelial progenitor cells in atherosclerosis. Front Biosci. 2012;17:2327-49.

PMid:22652782

20. van Oostrom O, Fledderus JO, de Kleijn D, Pasterkamp G, Verhaar MC. Smooth muscle progenitor cells: Friend or foe in vascular disease? Curr Stem Cell Res Ther. 2009;4(2):131-40. https://doi.org/10.2174/157488809788167454 PMid:19442197

21. Qingbo $X$. The impact of progenitor cells in atherosclerosis. Nat Clin Pract Cardiovasc Med. 2006;3(2):94-101.

PMid: 16446778 
22. Feil S, Fehrenbacher B, Lukowski R, Essmann F, SchulzeOsthoff $\mathrm{K}$, Schaller $\mathrm{M}$, et al. Transdifferentiation of vascular smooth muscle cells to macrophage-like cells during atherogenesis. Circ Res. 2014;115(7):662-7. https://doi. org/10.1161/circresaha.115.304634

\section{PMid:25070003}

23. Chappell J, Harman JL, Narasimhan VM, Yu H, Foote K, Simons BD, et al. Extensive proliferation of a subset of differentiated, yet plastic, medial vascular smooth muscle cells contributes to neointimal formation in mouse injury and atherosclerosis models. Circ Res. 2016;119(12):1313-23. https://doi.org/10.1161/circresaha.116.309799

PMid:27682618

24. Grebe A, Latz E. Cholesterol crystals and inflammation. Curr Rheumatol Rep. 2013;15(3):313. https://doi.org/10.1007/ s11926-012-0313-z

PMid:23412688

25. Gimbrone MA Jr., Garcia-Cardeña G. Vascular endothelium, hemodynamics, and the pathobiology of atherosclerosis.
Cardiovasc Pathol. 2013;22(1):9. https://doi.org/10.1016/j. carpath.2012.06.006

PMid:22818581

26. Majesky MW, Dong XR, Hoglund V, Mahoney WM Jr., Daum G. The adventitia a dynamic interface containing resident progenitor cells ATVB in focus vascular cell lineage determination and differentiation. Arterioscler Thromb Vasc Biol. 2011;31(7):15309. https://doi.org/10.1161/atvbaha.110.221549 PMid:21677296

27. Shimizu K, Sugiyama S, Aikawa M, Fukumoto Y, Rabkin E, Libby $\mathrm{P}$, et al. Host bone-marrow cells are a source of donor intimal smooth-muscle-like cells in murine aortic transplant arteriopathy. Nat Med. 2001;7:738-41. https://doi org/10.1038/89121

28. Sata $M$, Saiura $A$, Kunisato $A$, Tojo A, Okada $S$, Tokuhisa $T$, et al. Hematopoietic stem cells differentiate into vascular cells that participate in the pathogenesis of atherosclerosis. Nat Med. 2002;8(4):403-9. https://doi.org/10.1038/nm0402-403

PMid:11927948

\section{Appendixes}

Table A-1: Associations in heart muscle in the selected cases

\begin{tabular}{lll}
\hline Associations in heart & Frequency & Percent \\
\hline Concentric hypertrophy only & 1 & 1.6 \\
Free & 26 & 42.7 \\
Chronic ischemia only & 23 & 37.8 \\
Infarction & 10 & 16.3 \\
Reperfusion injury & 1 & 1.6 \\
Total & 61 & 100.0 \\
\hline
\end{tabular}

Table A-2: Exposure to trauma or stress among cases

\begin{tabular}{|c|c|c|c|c|}
\hline \multicolumn{5}{|c|}{ Stress or trauma } \\
\hline & Frequency & Percent & Valid percent & Cumulative percen \\
\hline No data & 24 & 39.4 & 39.4 & 39.4 \\
\hline Stress & 24 & 39.3 & 39.3 & 78.7 \\
\hline Trauma & 13 & 21.3 & 21.3 & 100.0 \\
\hline Total & 61 & 100.0 & 100.0 & \\
\hline
\end{tabular}

Table A-3: Weight of the heart in the selected cases

\begin{tabular}{lll}
\hline Weight of heart & Frequency & Percent \\
\hline $150-<350$ & 8 & 13.1 \\
$350-<500$ & 42 & 68.9 \\
$\geq 500$ & 8 & 13.1 \\
Total & 58 & 95.1 \\
Missing & 3 & 4.9 \\
Total & 61 & 100.0 \\
\hline
\end{tabular}

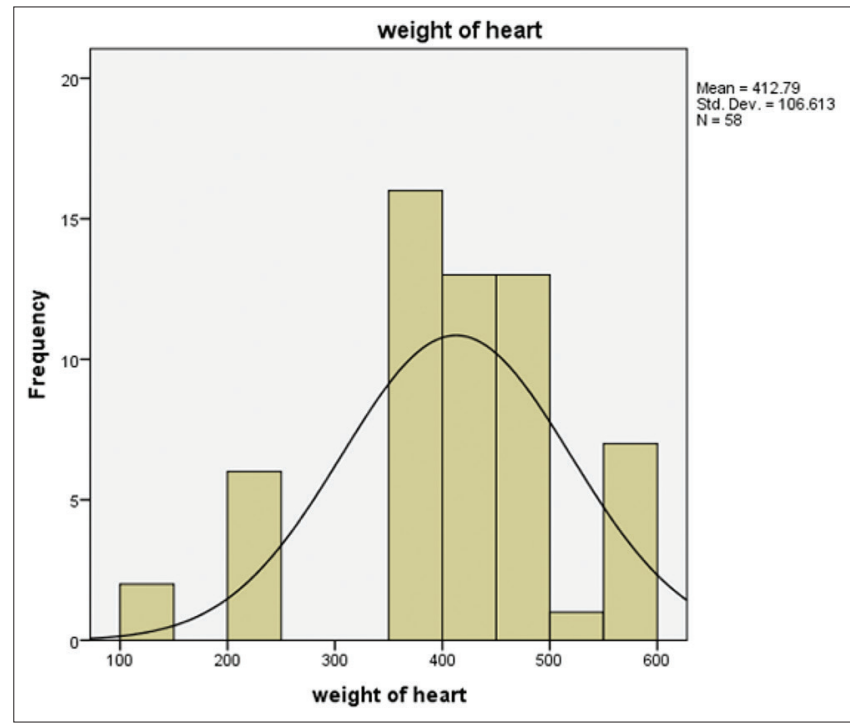

Figure A-1: Weight of the heart 




Figure A-2: Mean weight of the heart in different degrees of atherosclerosis

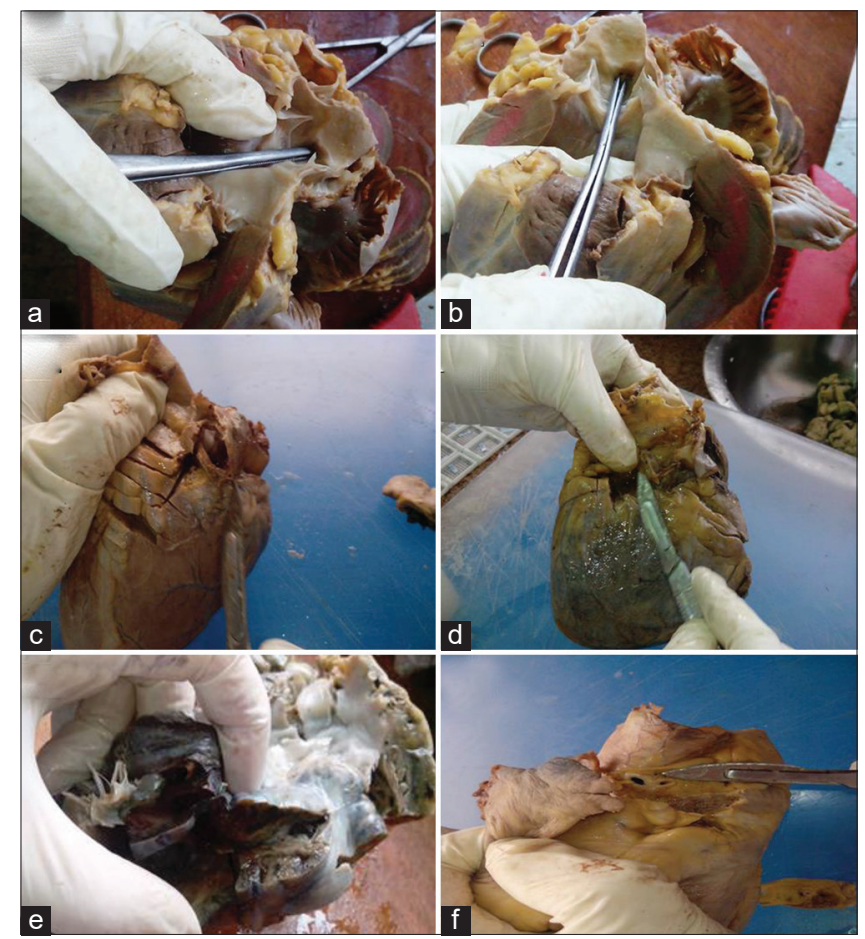

Figure (A-1): Opening of coronary arteries transversely (a) and (b) inspection of coronary ostia, (c) LAD starting from the middle, (d) left main coronary, (e) left circumflex, (f) right coronary 